\title{
DINAMIKA KEHIDUPAN KAUM AGAMAWAN ANALISIS WACANA KRITIS NOVEL LA FAUTE DE L'ABB É MOURET KARYA ÉMILE ZOLA
}

\author{
Hanafiah Azmi dan Teguh Basuki \\ Jurusan Sastra Prancis Fakultas Ilmu Budaya \\ Universitas Gadjah Mada \\ Email: hanafiah.azmi@mail.ugm.ac.id
}

\begin{abstract}
During the Second Empire, the development of educational field commenced the development in other fields, such as economics and politics. These could not be separated from the influence of the Church which at that time had a close relationship with the State. The emergence of a new social class, Bourgeoisie, had changed the life style of the society which initially oriented from the Lord to secular. They wanted a freedom of life from the control of the Church. The dominant role of the Church at first, it gradually shifted along with increasing role of the new social class. This research discussed about the life of the society during the Second Empire, represented by Émile Zola on the novel La Faute de l'Abbé Mouret through the life of the clergyman. The problems which arised from himself (internal) and of the surroundings (external), pushed the main character to leave his life in the Church and took off his status as a clergyman.
\end{abstract}

Keywords: The clergyman, Church, the Second Empire, Émile Zola, La Faute de l'Abbé Mouret

\begin{abstract}
ABSTRAK
Pada masa Kekaisaran Kedua, perkembangan di bidang pendidikan mengawali perkembangan bidang lain, seperti ekonomi dan politik. Hal ini tidak terlepas pengaruh dari Gereja yang pada saat itu memiliki hubungan yang erat dengan Negara. Munculnya kelas sosial baru bernama Borjuasi mengubah pola kehidupan masyarakat yang semula berorientasikan kepada Tuhan menjadi duniawi. Mereka menginginkan kehidupan yang bebas dari kontrol Gereja. Peran Gereja yang semula dominan, perlahan tergeser seiring bertambahnya peran kelas sosial baru tersebut. Penelitian ini membahas tentang kehidupan masyarakat pada masa Kekaisaran Kedua yang direpresentasikan oleh Émile Zola pada novel La Faute de l'Abbé Mouret melalui kehidupan kaum Agamawan. Permasalahan yang muncul dari dirinya sendiri (internal) dan dari lingkungan sekitar (eksternal), mendorong tokoh utama untuk keluar dari kehidupannya di Gereja dan melepas statusnya sebagai pastor.
\end{abstract}

Kata Kunci: Agamawan, Gereja, Kekaisaran II, Émile Zola, La Faute de l'Abbé Mouret 


\section{PENGANTAR}

Louis Napoléon-Bonaparté merupakan Presiden Republik I Prancis sekaligus pendiri dari Kekaisaran II. Selama memerintah, ia membangun Prancis di berbagai bidang. Dari sekian bidang, perkembangan paling mengesankan terjadi di bidang pendidikan, ekonomi, dan politik. Pada masa itu,banyak industri berdiri dan menjadi poros ekonomi rakyat, sehingga mereka memilih untuk menghabiskan waktu untuk berkebun dan berdagang. Akses rakyat untuk menuntut ilmu semakin terbuka dengan adanya UU tahun 1867 tentang pengadaan sekolahsekolah hingga ke tingkat dusun, sehingga makin memantapkan perkembangan Prancis dalam hal pendidikan. Napoléon III bahkan mengganti sistem pemerintahan dari monarki menjadi republik untuk mencegah terjadinya kekuasaan seumur hidup, seperti yang dikuatirkan rakyat pada raja-raja sebelumnya. Sayangnya, perubahan status negara tersebut hanya sebuah propaganda untuk menarik simpati serta kepercayaan rakyat akan roda pemerintahannya. Perlahan ia mencari beberapa orang yang dapat ia percayai dan menggulingkan orang yang berpotensi menjagal ambisinya menjadi penguasa mutlak. Selang empat tahun kemudian, ia mengeluarkan UUD untuk membentuk sebuah sistem pemerintahan yang otoriter dan bersifat presidensial (Carpentier\&Lebrun, 2011: 308, 311).

Pada awal ia menjabat sebagai Kaisar Prancis, Napoléon III melakukan banyak gebrakan yang membuat negaranya semakin maju. Di bidang pendidikan, ia membuka akses pendidikan untuk rakyat hingga ke tingkat dusun. Bersama agamawan, ia memperluas pengaruh Gereja di bidang pendidikan melalui sekolah-sekolah. Bahkan bisa dikatakan bahwa pada masa kekuasaannya, kehidupan Gereja berkaitan erat dengan kepentingan otoriter Kaisar (Weber, 2012:256). Ia menggandeng kalangan agamawan untuk ikut serta mengembangkan negara. Para pejabat pemerintahan pun berasal dari kalangan agamawan, sehingga apa yang dititahkan Negara maka itulah yang dilakukan oleh Gereja.
Potret kehidupan salah satu kelas masyarakat pada masa Kekaisaran II yaitu kelas agamawan. Kisah berlatar belakang kehidupan kaum agamawan direpresentasikan oleh banyak pengarang, salah satunya Émile Zola. Ia mempelajari kehidupan masyarakat di semua kelas pada saat itu untuk dituliskan ke dalam karyanya. Ia merangkai kisah berlatar belakang kaum bangsawan, kaum borjuasi,kaum pekerja dan kaum agamawan ke dalam seri Les Rougon-Macquart, histoire naturelle et sociale d'une famille sous le Second Empire (1868-1893) (Dari kumpulan novel karya Émile Zola yang membahas tentang kehidupan lima generasi keluarga Rougon-Macquart pada masa Kekaisaran II (sejumlah 20 novel). Novel satu dengan yang lainnya memiliki keterkaitan karena tokoh-tokoh yang ia ciptakan merupakan satu keluarga RougonMacquart. Keluarga tersebut mencakup tiga kelas masyarakat yang terdapat di Prancis pada saat itu. Novel La Faute de l'Abbé Mouret adalah novel kelima dari seri Les RougonMacquart yang terbit pada tahun 1875. Novel ini menceritakan kehidupan kaum agamawan di tengah gejolak kepercayaan masyarakat kepada pemerintah yang berimbas pada bergesernya peran Gereja pada kehidupan mereka.

Novel La Faute de l'Abbé Mouret dan kaum agamawan telah banyak dilakukan. Frederick Brown mengungkapkan dalam artikelnya yang berjudul The Naturalist-Zola : A life(1995). Ia membahas tentang gaya kepenulisan Zola yang memilih aliran naturalis dalam karyanya karena ia ingin fokus pada kehidupan yang terjadipada saat itu. Sebuah artikel berjudul Quelle est La Faute de l'Abbé Mouret? Pour une Narratologie Diachronique et Polémique oleh Mieke Bal (1986) membahas tentang tokoh-tokoh dalam novel tersebut secara mendalam dengan menggunakan konsep naratologi sesuai dengan apa yang tertulis di dalam novel disertai makna tersirat atas aksi yang dilakukan oleh para tokoh. Artikel lainnya berjudul A Study of the Priest Type In the Novels of Édouard Estaunié(1922) ditulis oleh Christina Crane, menjelaskan 
cara Édouard Estaunié menggambarkan tokoh - tokoh yang ia ciptakan dalam novelnovelnya, khususnya tokoh pastor yang terdapat pada beberapa novelnya seperti L'Empreinte, La Vie secrète (Taffin), L'Appel de la route (Manchon, Valfour), Tels qu'ils furent (Monseigneu), L'Epave (Salomon),dan Les Jauffrelin (Rouville). Dari tinjauan pustaka di atas, belum ada yang membahas tentang kehidupan kaum agamawan pada novel La Faute de l'Abbé Mouret karya Émile Zola. Oleh karena itu, penelitian ini layak untuk dilakukan, terutama untuk memperlihatkan bagaimana kehidupan kaum agamawan di masa Kekaisaran Kedua, sekaligus menunjukkan bagaimana kritik yang ingin disampaikan oleh Zola terhadap kehidupan di balik tembok Gereja di masa itu yang seringkali identik dengan banyak rahasia dan peraturan yang ketat.

Sebagimana diketahui, semangat zaman pada abad ke-18 didasarkan atas cita-cita tentang hak dan kemerdekaan manusia, baik dalam dalam berpendapat maupun bertingkah laku (Kuntowijoyo, 2005:158). Hal itu juga berimbas pada perkembangan dunia ekonomi, pendidikan dan politik di Prancis pada saat itu, yang kemudian menggeser pola pikir dan pola hidup masyarakat yang sebelumnya percaya pada agama kemudian menjadi tidak peduli. Ketidakpedulian masyarakat tersebut seringkali diatas namakan kebebasan dalam berpendapat dan berpikir. Sehingga tidak bisa dipungkiri bahwa hal yang demikian berimbas pada kehidupan agamawan pada saat itu. Cita-cita duniawi masyarakat industrial menguatkan posisi orang awam dan meruntuhkan kedudukan agamawan. Hal itulah yang kemudian digambarkan oleh Zola dalam novelnya La Faute de l'Abbé Mouret.

Tulisan ini akan melihat bagaimana permasalahan yang dialami oleh Serge Mouret sebagai tokoh utama dalam kaitannya dengan (a) dinamika kehidupannya sebagai pastordi tengah naik turunnya kepercayaan rakyat terhadap Gereja; (b) kritik Émile Zola terhadap kehidupan Gereja di bawah Kekaisaran II yang disampaikan melalui penggambaran tokoh Serge Mouret.
Penelitian ini akan menggunakan pendekatan sosiologi sastra dari Lucien Goldman, di mana melihat sosiologi sastra sebagai usaha untuk menjelaskan produksi, struktur dan cara fungsi (pembacaan, penerjemahan) dari teks sastra dalam konteks sosial, historis, dan institusional (Goldmann via Oekoen). Pada pendekatan ini akan terlihat adanya penempatan ideologi/pandangan dunia sebagai mediasi antara masyarakat dan sastra. Selain itu, di dalamnya terdapat pula usaha untuk memberikan status yang relatif otonom pada kesusastraan sebagai lembaga sosial. Lebih lanjut, karya sastra dilihat sebagai satu hal yang selalu berhubungan dengan suatu masyarakat tertentu tempat karya tersebut diciptakan.

\section{PEMBAHASAN Abbé Mouret dan Kehidupan Pastor dalam Novel La Faute de l'Abbé Mouret}

Novel La Faute de l'Abbé Mouret berlatar belakang kehidupan kaum agamawan di Prancis pada masa Kekaisaran II. Novel ini terdiri dari tiga bagian yang dibagi lagi dalam 17 bab. Bagian pertama mengisahkan aktivitas Serge Mouret, atau yang lebih dikenal dengan sebutan l'Abbé Mouret, seorang pastor di desa Les Artaud. Ia tinggal bersama adiknya, Désirée Mouret dan seorang pembantu tua bernama La Teuse. Setiap hari ia menghadapi aktivitas yang sama seperti melayani misa, pengakuan dosa, dan peribadatan lainnya. Rasa bosan kemudian hinggap di dirinya. Hingga pertemuannyaa dengan Albine dan kehidupan masyarakat di luar Gereja yang lebih dinamis menimbulkan pergolakan di batin Mouret. Ia pun tergoda untuk melanggar sumpah pastor. Bagian kedua kisah Mouret yang hilang ingatan dan dibawa oleh pamannya, dokter Pascal Rougon, menuju desa Paradou untuk dirawat oleh Albine. Kebersamaan mereka yang tak diketahui siapa pun menumbuhkan benih-benih cinta di antara keduanya. Sayangnya pada saat perjalanan terakhir, mereka bertemu dengan Frère (Gelar kepala biara, pastor, rama) Archangias dan sontak 
membuat ingatan Mouret akan masa lalunya kembali. Bagian ketiga menjelaskan tentang kembalinya Mouret ke Gereja. Akan tetapi, ia berubah menjadi sosok yang lebih pendiam dan sering merenung seiring dengan pergolakan batin yang ia alami sejak hubungannya putus dengan Albine. Dorongan pamannya untuk menemui Albine yang sedang sakit menumbuhkan kembali benih-benih cintanya, namun pada akhirnya ia memutuskan untuk meninggalkan Albine dan kembali ke gereja.

Secara garis besar, novel ini menceritakan detail kehidupan kaum agamawan Katolik pada masa Kekaisaran II. Kaum ini terikat oleh sistem hierarki gereja yang mengklasifikasikan mereka ke dalam beberapa tipe. Secara umum, tugas mereka sama yaitu sebagai pemuka agama yang bertugas memimpin jemaat gereja menuju jalan keselamatan. Secara khusus, tugas mereka dibedakan berdasarkan ruang lingkup kerja mereka.

Pada novel ini, Zola tidak luputjuga menceritakan kehidupan abbé (Sebutan sesama manusia sebagai keluarga dunia, mereka yang seagama, bruder), frère dan petugas Gereja (diaken dan sub-diaken) (Pembantu uskup dan pastor dalam mengerjakan kewajiban-kewajiban di gereja (Blockmans \& Hoppenbrouwers, 2007: 48). Posisi kaum agamawan pada saat itu berada tepat di bawah kelas bangsawan yang terdiri atas raja dan semua keturunannya, sehingga seringkali disebut sebagai anak emas kaum bangsawan (Blockmans \& Hoppenbrouwers, 2007: 48). Tak pelak, kaum agamawan memiliki posisi istimewa karena selain menjabat sebagai pemimpin agama, mereka juga berhak menduduki posisi pemerintahan. Bersama raja, mereka turut mengambil keputusan dan memberlakukan kebijakan-kebijakan kepada rakyat. Mereka tinggal diGereja dan melayani peribadatan terutama misa, pengakuan dosa, ekaristi (Misa perjamuan makan malam terakhir Yesus bersama para rasulnya sebelum disalib), dan pembaptisan. Uskup dan pastor wajib memiliki kemampuan dalam menjelaskan isi Injil kepada jemaat dalam pengajaran agama yang diselenggarakan di Gereja (katekismus). Keberadaan mereka terikat sumpah kepastoran. Seseorang yang telah berkeluarga dapat diangkat menjadi pastor, sedangkan seorang lajang yang diangkat menjadi pastor dilarang untuk menikah. Mereka wajib mengabdikan diri mereka kepada pelayanan umat dan menjadi wakil Tuhan(Blockmans\&Hoppenbrouwers, 2007:48).

Kehidupan di dalam Gereja diceritakan secara detail oleh Zola dalam novel ini, seperti pada bagian pertama novel ini (bab I dan II), yang dibuka dengan ritual misa (Ibadah umat Kristiani dalam rangka merayakan hari Tuhan. Dilakukan di hari Sabtu sore atau Minggu (Listiati, 2013)). Setting novel pada dua bab tersebut berada di dalam Gereja. Tidak sekalipun Mouret berpindah tempat di luar Gereja tersebut. Selama beberapa tahun, Mouret bahkan tidak bersentuhan dengan sinar matahari (Zola, 1875:28). Tak ayal, bagi Mouret, Gereja tak ubahnya sebuah penjara yang mengungkung dirinya. Hal ini secara tidak langsung memang menggambarkan kehidupan agamawan yang terikat dengan aturan dan berjalan seperti mesin dengan aktivitas yang terus berulang. Oleh karena itu, Mouret merasa gembira begitu menginjakkan kakinya di luar Gereja dan lepas sejenak aktivitas yang menurutnya membosankan.

Di luar Gereja, Mouret menyaksikan kehidupan masyarakat yang lebih dinamis, seperti realita yang memang terjadi di masa pemerintahan Napoléon III. Saat itu, ekonomi Prancis berkembang dengan adanya sistem feodalisme. Sistem ini mendorong rakyat untuk giat mengumpulkan uang dan membeli tanah. Kemudian mereka mempekerjakan orang, menjual hasil yang didapat dari lahannya dan menjadi kaya karenanya. Tidak berhenti sampai disini, mereka menggunakan kekayaan yang mereka miliki untuk menaikkan kelas sosial (Weber, 2012: 272). Dengan demikian, mereka memiliki privilese sosial, meski menempati posisi lebih rendah dibandingkan kaum bangsawan (Ibid,269). Dipandang dari sisi 
kaum agamawan, hal ini merugikan posisi mereka, karena masyarakat mulai berpaling dari kepercayaan pada Tuhan dan mulai menghamba pada pekerjaan serta uang.

"Depuis quinze ans, je n'en ai pas connu une qui ne soit allée dans les blés avant de passer à l'église... Et elles prétendent en riant que c'est la coutume du pays!" (Zola, 1875: 37)

"Sudah lima belas tahun, saya belum pernah melihat seorang pun pergi ke ladang dengan melewati Gereja... dan mereka mengelak sambil bergurau mengatakan bahwa Gereja sudah menjadi budaya lawas!"(Zola, 1875: 37)

Melalui perkataan Frère Archangias di atas, Zola menggambarkan kondisi masyarakat Les Artaudyang mementingkan untuk berladang dan berkebun dibanding pergi ke Gereja.Rakyat menjadi lebih sibuk bekerja dan mengindahkan agama.

Berdasarkan penjelasan tersebut, tampak bahwa pola hidup masyarakat yang semula berpusat pada agama bergeser ke arah ekonomi dan pendidikan, yang dipandang lebih rasional. Agama dengan segala dogma yang mengatur kehidupan, dianggap oleh masyarakat menghalangi keinginan mereka untuk naik kelas sosial. Doktrin tentang dosa bawaan (original sin) (Konsep pada agama Katolik tentang dosa asal yang dibawa oleh Adan dan Hawa dan diturunkan kepada semua keturunannya (Iman katolik, 2013)) yang menghambat semua keinginan alamiah manusia, melenyapkan selera dan menghambat kemajuan kemampuan, tergantikan doktrin tentang kesempurnaan manusia yang ingin memenuhi tuntutan-tuntutan alamiah dan mengembangkan kemampuan mereka(Kuntowijoyo, 2005:163).

Zola memberi contoh melalui kehidupan masyarakat Les Artaud yang berpaling dari Gereja, untuk menunjukkan bahwa perlahanlahan Gereja hanya merupakan sebuah bangunan, sama seperti bangunan lainnya. Ia ada, tetapi tidak berfungsi sebagaimana mestinya. Sejalan dengan itu, krisis mulai muncul dengan terlibatnya Prancis pada berbagai perang. Naiknya kebutuhan negara mendorong lahirnya kebijakan baru, yaitu kenaikan angka pajak (Carpentier \& Lebrun, 2011: 255). Kebijakan ini ditentang oleh banyak kalangan karena semakin banyak rakyat yang berpendidikan, membuat mereka sadar bahwa kebijakan ini sematamata hanya demi kepentingan negara dan kaum agamawan semata. Rakyat kemudian membenci agamawan dan institusinya yaitu Gereja. Inilah yang mendorong rakyat untuk mengakhiri peran Gereja atas kehidupan bernegara.

Pola hidup masyarakat yang mulai acuh pada Gereja, membuat Mouret ragu untuk mempertahankan statusnya sebagai pastor. Pada suatu kesempatan, Mouret diajak pamannya, dokter Pascal untuk mengunjungi suatu desa bernama Paradou. Disana ia bertemu dengan seorang lelaki tua bernama Jeanbernat yang tinggal bersama keponakannya, Albine. Sebagai seorang pastor, Mouret berusaha menjaga jarak antara dirinya dengan sang gadis. Akan tetapi sifat Albine yang periang berhasil meninggalkan kesan untuk Mouret. Berulang kali ia menyendiri untuk merenungkan status dan sumpah pastornya yang bertentangan dengan keinginannya dalam menjalin hubungan dengan lawan jenis. Ia berusaha untuk menangkis semua hal yang berpotensi menggoyahkan sumpahnya. Akan tetapi tanpa ia sadari, muncul sosok Albine dalam benaknya.

"Il fermait ses sens, il essayait de les anéantir. Mais, devant lui, Albine reparut comme une grande fleur, poussée et embellie sur ce terreau. Elle était la fleur naturelle de ces ordures, délicate au soleil, ouvrant le jeune bouton de ses épaules blanches, si heureuse de vivre, qu'elle sautait de sa tige et qu'elle s'envolait sur sa bouche, en le parfumant de son long rire." (Zola, 1875: 134)

"Ia menutup segala perasaannya, ia mencoba untuk menangkisnya. Namun, di depannya, Albine hadir bagaikan sekuntum bunga, yang tumbuh dan terlihat elok berkat humus. Dia bagaikan bunga alami terlihat dari sampahsampah itu, yang lembut disinari mentari, membuka kuncup bunga dari bahu-bahunya 
yang putih, yang menyenangkan untuk dilihat, dia petikkan tangkainya dan dia tiupkan, sembari merasakan tawa renyahnya."(Zola, 1875: 134)

Sayangnya, aturan di Gereja tidak memungkinkannya untuk memiliki seorang pendamping wanita karena ia telah mengikat diri dalam sebuah sumpah kepastoran yang melarang pastor lajang seperti dirinya untuk menikah (Blockmans \& Hoppen brouwers, 2007: 47).

Seiring waktu, Mouret justru meruntuhkan sumpahnya sendiri untuk tidak berhubungan dengan lawan jenis dan menikah (Zola, 1875:173). Mouret merasa bahagia karena bebas dari ikatan Gereja yang dulu mengekangnya. Bahkan ia tidak mau lagi mendengar lonceng Gereja karena trauma terhadap kehidupannya dulu sebagai pastor yang dirasa sangat mengekang. Sayangnya, keinginannya untuk terus bersama dengan Albine ternyata tidak bisa bertahan lama. Suatu hari, mereka bertemu dengan Frère Archangias, pastor dari Gereja yang selama ini membuntuti Mouret untuk mengajaknya kembali ke Gereja. Ia memberi perintah bagi Mouret untuk kembali ke Gereja dengan membawa-bawa nama Tuhan untuk membuat Mouret merasa bersalah.

"Lachez-la, ne la touchez plus, car elle est le commencement de l'enfer... Au nom de Dieu, sortez de ce jardin!"'(Zola, 1875: 279)

"Lepaskan dia, jangan sentuh dia lagi, karena dia adalah awal dari sebuah neraka. Atas nama Tuhan, keluarlah dari kebun ini." (Zola, 1875: 279)

Dari kalimat di atas, tampak bahwa Frère Archangias bertindak selaku pihak superior. Melalui statusnya sebagai sesama pihak agamawan, ia berusaha exercising power terhadap Mouret yang kemudian berpengaruh dalam pengambilan keputusan hidup Mouret. Dari sini, Zola ingin menyindir bagaimana kehidupan di dalam Gereja sangat ketat, dengan hierarki jabatan yang mengekang setiap individu di dalamnya agar tunduk pada semua aturan, terutama yang mengatasnamakan Tuhan. Dalam hal ini, posisi Mouret sebagai junior dari Frère Archangias membuatnya tidak berkutik ketika dikonfrontir mengenai keputusannya untuk keluar dari gereja.

Pengaruh Frère Archangias sangatlah kuat, hingga akhirnya Mouret memutuskan untuk kembali ke Gereja. Meski demikian, ia menjadi pribadi yang lebih tertutup dan sering melamun. Ingatan masa lalunya masih menggoncang batinnya terutama bayangbayang dosa yang ia lakukan sebelumnya bersama Albine.

Sayangnya, keimanan Mouret yang tinggi-terlepas dari pengaruh Frère Archangiasternyata tidak dimiliki oleh orang-orang terdekatnya. Pamannya,dokter Pascal, sama sekali tidak pernah berpikir untuk merujuk kepada Gereja jika ia memiliki masalah. Gelarnya sebagai dokter menegaskan pola pikirnya yang sudah terasionalisasi sehingga ia cenderung menolak keberadaan Tuhan.

Sementara itu, Albine semakin menderita ditinggalkan Mouret. Ia kemudian pergi ke Gereja dengan tujuan mengajak Mouret kembali padanya, namun Mouret tetap pada pendiriannya untuk kembali pada kehidupannya sebagai pastor. Albine tidak menyerah begitu saja. Ia terus bercerita tentang kenangan yang pernah mereka buat bersama di kala mereka masih bersama (Zola, 1875:346). Sayangnya, Mouret terus menolak hingga akhirnya Albine marah dan mengungkapkan ketidakpercayaannya pada Tuhan dan Gereja.

"Qui ça Dieu? cria Albine affolée, redevenue la grande fille lâchée en pleine nature. Je ne le connais pas, ton Dieu, je ne veux pas le connaître, s'il te vole à moi... Mon oncle Jeanbernat a donc raison de dire que ton Dieu est une invention de méchantceté, une manière d'épouvanter les gens et de les faire pleurer... Tu mens, tu ne m'aimes plus, ton Dieu n'existe pas." (Zola, 1875:349)

"Siapa itu Tuhan? teriak Albine yang pikirannya semakin kacau, ala seorang gadis yang terbiasa hidup di alam bebas. Aku tak mengenalnya, bahkan tidak mau mengenalnya, jika dia merampasmu dariku... Ada benarnya berarti Paman Jean- 
bernat yang berkata bahwa Tuhanmu itu tipuan jahat belaka, yang menakut-nakuti manusia dan membuat mereka menangis... Kau bohong, kau tidak cinta lagi padaku, Tuhanmu tidaklah ada."(Zola, 1875:349)

Dari perilaku dua tokoh utama di atas -dokter Pascal dan Albine- yang tidak terang-terangan menyatakan ketidakpercayaan terhadap Gereja, Zola hanya menyisakan Mouret sebagai satu tokoh yang masih terombang-ambing di antara hasrat duniawi dan keimanan terhadap Tuhan. Bila ditarik benang merah dari semua upaya Mouret dalam membela diri, ia berdiri sebagai seorang kaum agamawan yang menganggap Tuhan sebagai jalur keselamatan. Menurutnya hukum alam adalah hukum Tuhan. Doktrin tentang hukum tersebut melekat kuat padanya dengan ia merasa dosa dan perlu untuk membenahi diri. Menurut Weber bahwa tak peduli seberapa kuat nubuat (Pengetahuan akan hal-hal yang terjadi di masa mendatang (Tay dan Listiati, 2013) dan konsep kognitif suatu tatanan yang diperjuangkan nabi, selalu ada aspek non-kognitif yang krusial, yaitu komitmen untuk mematahkan (Weber, 2012: 39). Hal ini serupa yang terjadi dengan Mouret selanjutnya. Ia kembali hanyut dalam meditasi yang membawanya pada dua pilihan yaitu kembali pada Albine atau melupakannya

"Était-ce une damnation d'aimer Albine? Non, si cet amour allait au-delà de la chair, s'il ajoutait une espérance au désir de l'autre vie. Puis, comment fallait-il l'aimer? Sans une parole, sans un pas vers elle, en laissant cette tendresse toute pure s'exhaler ainsi qu'une bonne odeur, agréable au ciel." (Zola, 1975:363)

"Salahkah diriku apabila mencintai Albine? Tidak, jika cinta ini memang begitulah seharusnya, bila dia berkehendak untukku mengarungi dunia lain. Tapi bagaimana aku bisa mencintainya? Tanpa kata, tanpa menghampirinya, dengan hanya membiarkan kelembutan ini yang murni berhembus layaknya wangi yang harum, melayang terbang ke langit." (Zola, 1975:363)
Setelah bermeditasi, ia justru ingin kembali pada Albine dan meninggalkan Gereja untuk kedua kalinya. Akan tetapi, dalam perjalanan untuk menemui Albine, ia justru dibayangi oleh rasa takut akan dosa yang lebih besar dari sebelumnya dan pesona Gereja yang menurutnya lebih agung dibanding rasa cintanya pada Albine yang hanya sesaat (Zola, 1875:399).

"Moi, je ne pouvais passer devant une église
sans y entrer. Dès que la porte retombait
silencieusement derrière moi, il me semblait que
j'étais dans le paradis lui-même, avec des voix
d'ange qui me contaient àl'oreille des histoires de
douceur, avec l'haleine des saints et des saintes
dont je sentais la caresse par tout mon corps...
Oui, j'aurais voulu vivre là, toujours, perdu au
fond de cette béatitude." (Zola, 1875: 399)

"Aku, tidak bisa pergi ke Gereja tanpa masuk ke dalamnya. Begitu pintu tertutup dengan pelan di belakangku, aku bagaikan berada di surga Gereja tersebut, mendengar suara malaikat yang membisikkan cerita tentang kedamaian, dengan nafas para santo sehingga aku merasakan kelembutan yang dirasakan oleh sekujur tubuhku... Ya, aku ingin hidup disana, selalu, menghilang ke dalam keindahan itu semua." (Zola, 1875: 399)

Gereja dengan segala keindahan yang dirasakan oleh Mouret memberikan pengaruh yang luar biasa terhadap garis hidupnya. Pada akhirnya, ia memilih untuk kembali pada kehidupannya sebagai pastor, dan mengurungkan niat untuk memperistri Albine. Perempuan muda yang patah hati itupun akhirnya memutuskan untuk mengakhiri hidupnya karena rasa sedih yang tidak dapat ditanggungnya lagi.

Sampai di sini, Zola dengan gamblang menceritakan mengenai kisah tragis seorang manusia yang harus diombang-ambingkan antara keinginan untuk bersama dengan orang yang dikasihi, atau memenuhi janji untuk hidup selibat. Zola juga menceritakan bahwa meski tindakan Mouret tidak bisa dibenarkan, karena ia sudah menyatakan sumpah untuk hidup selibat, namun 
kekangan yang diberikan oleh gereja melalui Frère Archangias pun tidak bisa dianggap tepat. Ideologi dan kritik Zola terhadap kekuasaan gereja di masa Kekaisaran Kedua akan disampaikan dalam paparan selanjutnya di bawah ini.

\section{Ideologi dalam Novel La Faute de l'Abbé Mouret}

Émile Zola, sebagai seorang pengarang, telah membuat Les Rougon Macquart menjadi karya yang indah, tragis, dan sarat makna mengenai kehidupan di bawah Kekaisaran Kedua. Sebagai seorang kritikus, Zola menggunakan karya sastra sebagai media untuk menyampaikan kritiknya terhadap beberapa hal yang terjadi di Prancis. Ia memasukkan pandangannya terhadap kondisi sosial masyarakat pada masa itu melalui jalannya cerita dari setiap karya sastranya. Dalam novel La Faute de l'Abbé Mouret, Zola memberikan ideologi sosial mengenai hubungan Gereja dan Negara serta dominasi kaum agamawan dalam sendi kehidupan masyarakat Prancis.

Zola mengungkapkan bagaimana hubungan antara Gereja dengan Negara dalam novelnya. Pada tingkat sederhana, Gereja telah memperlihatkan dominasinya bagi semua orang yang ada di dalamnya, tak terkecuali Mouret. Pada novel La Faute de l'Abbé Mouret, Mouret digambarkan sebagai pribadi yang terikat hukum Tuhan dengan dosa yang terus membayanginya. Ia tidak memiliki pilihan lain selain tunduk dan patuh pada Gereja. Hal-hal tersebut tidak terlepas dari kritik Zola terhadap Gereja dan kuasanya yang mempengaruhi kehidupan pribadi tiap manusia serta tindak-tanduk Negara Prancis.

Begitu kuatnya pengaruh Gereja terhadap kehidupan masyarakat kala itu, sehingga menjadikan banyak orang dari kelas bawah (tiers-états) yang memilih untuk menjadi agamawan agar mendapat perlindungan dan jaminan hidup yang lebih layak. Tak terkecuali Mouret dengan keputusannya untuk menjadi pastor di Les Artaud. Secara sederhana bahwa logika yang disampaikan Zola, jika memang ada individu tertentu yang ingin menjadi pastor atau bagian dari kehidupan Gereja, maka mereka tidak akan tergoda untuk berpaling, meski ada perempuan atau tawaran harta yang berlimpah. Terlepas dari anemsia yang dialami, Mouret diceritakan sempat memilih untuk bersama dengan Albine dan berkeinginan untuk keluar dari Gereja. Hal itu menggambarkan bagaimana terkadang pilihan untuk menjadi pastor tidak muncul dari kesadaran pribadi, tetapi lebih dengan melihat beberapa privilese yang ditawarkan oleh institusi Gereja.

Pada tingkat yang lebih luas, Zola juga mengritik aliansi antara Gereja dan Negara. Di bidang politik, Gereja memanfaatkan hubungan baiknya dengan Raja untuk memasukkan kaum agamawan di pemerintahan dan agar mereka bisa masuk dalam struktur Negara (Carpentier \& Lebrun, 2011: 281). Selain memberikan dukungan penuh kepada raja dan bangsawan, mereka juga terlihat hanya memperjuangkan kepentingan mereka sendiri. Hal itu terlihat ketika Negara dalam keadaan krisis, Gereja tidak memihak rakyat dan justru mendukung keputusan Negara untuk menaikkan beban pajak kepada rakyat.

Di dalam kehidupan sosial, peran mereka tertanam kuat hingga ke tingkat paroki. Hal ini dipengaruhi oleh sistem hierarki Gereja yang sangat terstruktur, sehingga memungkinkan para agamawan untuk bekerja hingga ke tingkat paling dasar, yaitu pada kehidupan masyarakat.

Di bidang ekonomi, Gereja juga berfungsi sebagai lumbung kekayaan Negara berkat properti-propertinya dan pajak yang diberlakukan kepada rakyat (Houtart \& Rousseau, 1971: 29). Gereja menjadi tulang punggung Negara dengan pajak yang diberlakukan pada semua umat Katolik. Peran Gereja semakin vital dengan kekayaan yang semakin bertambah. Dalam hal ini, terdapat hegemonic control yang dilakukan oleh kelas dominan, yaitu agamawan, terhadap institusi-institusi Negara (Fairclough, 1875: 93).Melalui kekayaan yang dimiliki tersebut, Gereja berusaha menumbuhkan peran 
dan kontrolnya di setiap aspek hingga ke kehidupan antar individu.

Menurut Fairclough, hegemoni dilakukan oleh kelas dominan untuk melanggengkan kekuasaan yang dimiliki. Dalam novelnya, Zola mengkritik hal tersebut dengan memperlihatkan bagaimana masyarakat di Les Artaud membenci Gereja dan tidak mau pergi ke sana karena muak terhadap pajak yang diberlakukan oleh Gereja. Ia melukiskan agama dan Gereja sebagai hal yang menakutkan untuk didekati melalui salah satu tokohnya yaitu Frère Archangias. Karakternya mewakili kejahatan dan dominasi kaum agamawan pada masa itu.Meskipun demikian, masyarakat tidak memiliki pilihan lain selain tunduk oleh Gereja yang mengatasnamakan Tuhan. Di sini, terlihat bagaimana teks-teks keagamaan dalam kitab suci dijadikan kaum agamawan sebagai tameng untuk mengontrol kehidupan masyarakat (Weber, 2012: 44). Rakyat pada masa itu dibayangi oleh ancaman dosa apabila tidak mengindahkan agama, persis seperti apa yang dilakukan oleh Frère Archangias kepada Mouret ketika ia tidak mau kembali ke Gereja. Hal yang sama juga dilakukan olehnya kepada Albine ketika wanita tersebut menyatakan keinginannya untuk kembali bersama Mouret. Rasa cinta Mouret kalah dengan ketakutannya kepada dosa yang ditulis di Injil.

Tulisan oleh John Mc Manners (1998:23) menyatakan bahwa Gereja ibarat kapal yang dikomandani oleh seorang pilot yang menangani urusan kegerejaan setiap harinya dan ditemani seorang pengontrol keamanan yang akan turun tangan apabila terdapat permasalahan dan mencegah terjadinya kapal karam. Pilot tersebut berada di dalam Gereja dan pengontrol keamanan yang dimaksud merupakan kaum agamawan yang duduk di kursi pemerintahan. Adanya aliansi antara Negara dengan Gereja, membuat kaum agamawan mendapatkan privilese di antara kelas sosial yanglain. Secara struktural, posisi mereka memang berada di bawah kaum noblessedan di atas tiers-état, tetapi dalam kenyatannya, posisi kaum agamawan berada sebagai penghubung antara kaum noble dan tiers-état. Menurut kaum agamawan, kekuasaan tertinggi terletak pada kuasa Tuhan. Hal ini sejalan dengan status kaum agamawan sebagai wali Tuhan.

Sejak dinyatakannya kuasa Gereja atas Negara, mereka tidak lepas tangan dari setiap aktivitas kaum noble dan tiers-état. Campur tangan Gereja terhadap permasalahan Negara termasuk dalam hal pengadaan kebijakan publik. Mereka mengatas namakan Negara dalam mengadakan kebijakan. Hal ini menimbulkan rasa benci terutama di pihak tiers-état sebagai sasaran langsung kebijakan tersebut. Perubahan zaman dengan perkembangan pola pikir yang semakin kritis membuat mereka berniat untuk menghancurkan aliansi Gereja terhadap Negara.

Pergerakan tersebut dimulai dari keinginan tiers-état untuk menaikkan kelas sosial mereka. Pada awalnya, mereka bergerak melalui kegiatan bertani, berdagang dan perindustrian. Ketiganya saling bekerja sama untuk memberi pengaruh besar pada pertumbuhan ekonomi Negara. Mereka yang berhasil mengais rejeki dari aktivitas ekonomi tersebut, menggunakan harta mereka untuk memperkaya diri. Hasilnya, lahirlah kaum borjuasi. Mereka adalah roda penggerak ekonomi Negara dan tumbuh menjadi kelas sosial yang perlu diperhitungkan keberadaannya (Houtart \& Rousseau, 1971: 28). Kekayaan menjadi basis dari kemajuan intelektual dan sosial. Mereka menggunakan kekayaan yang mereka miliki untuk bergerak di bidang politik. Salah satunya dengan masuk ke partai-partai dan memperebutkan kursi kekuasaan. Melalui partai, mereka berusaha membuat perubahan sosial dengan melahirkan kebijakan-kebijakan baru.

Peran kelas sosial baru yang datang dari kaum awam tersebut merisaukan pihak agamawan dan mengganggu konsistensi mereka. Kaum tersebut berusaha mengurangi peran Gereja dan kaum agamawan, diantaranya dengan cara menggaungkan kebebasan dalam agama. Bersamaan dengan itu, mereka mencoba memisahkan pendidikan dari kontrol pihak Gereja (Stearns, 
1967: 186-187). Pergerakan-pergerakan kecil tersebut mengawali perubahan besar yaitu memisahkan aliansi Gereja dengan Negara.

Tercantum pada novel La Faute de l'Abbé Mouret, kegiatan berkebun menjadi gambaran dari aktivitas ekonomi masyarakat Prancis pada saat itu. Jeanbernat dan masyarakat Artaud sibuk berkebun sebagai langkah awal untuk menaikkan kelas sosial mereka menjadi kaum borjuasi. Menjadi pejabat dan memiliki tanah garapan dianggap lebih penting dari aktivitas berdoa seperti yang dilakukan Mouret setiap harinya. Mereka juga jarang pergi ke Gereja, sehingga menjadikan Gereja menjadi bangunan yang mati dan sepi dari aktivitas. Tindakan masyarakat Artaud tersebut dapat dikatakan merupakan salah satu upaya untuk menyingkirkan agamawan seperti Mouret.

Di sini, terdapat pertentangan kelas agamawan (yang diwakili oleh Mouret dan Archangias) dengan kelas borjuasi (yang diwakili oleh Jeanbernat, Bambousse) serta masyarakat Les Artaud. Kedua pihak tersebut sama-sama ingin diakui keberadaannya. Hal ini mengindikasikan kritik sang pengarang mengenai kelas sosial yang ada pada masa itu. Kelas sosial yang selama berabad-abad ada, justru semakin mempertajam jurang ketidaksetaraan. Kekuasaan seakan hanya milik kaum bangsawan, hidup mati seseorang seakan hanya diatur oleh Tuhan melalui kuasa kaum agamawan, dan kesengsaraan hanya milik kaum pekerja.

\section{SIMPULAN}

Novel La Faute de l'Abbé Mouret, Zola sebenarnya sedang menyampaikan kritik terhadap Gereja di bawah Kekaisaran II. Ia menggambarkan dominasi Gereja di dalam kehidupan Mouret sebagai salah satu pastor di Les Artaud, serta perilaku masyarakat yang acuh terhadap Gereja. Melalui novel ini pula, Zola menggambarkan kondisi Prancis yang pada saat itu sedang berkembang menjadi sebuah Negara dengan sektor ekonomi yang kuat. Pengaruh antara dunia pertanian dan perdagangan mempengaruhi masyarakat untuk lebih condong kepada kehidupan duniawi dan mengesampingkan agama. Kuasa Gereja yang mempengaruhi kehidupan masyarakat sudah dianggap tidak berarti lagi. Rakyat muak dengan perlakuan Gereja yang semena-mena mengatur kehidupan masyarakat dan Negara demi keuntungan kaum agamawan sendiri. Mereka berpikir untuk membebaskan diri dari kuasa Gereja sehingga bisa mengatur hidup mereka sendiri.

Apabila dikaitkan dengan teori Sosiologi Agama Max Weber dengan La Faute de l'Abbé Mouret, terlihat bahwa kaum agamawan menjadi golongan yang istimewa di mata masyarakat berkat kemampuan mereka di bidang agama. Hubungan yang dekat antara institusi tersebut dengan Negara dimanfaatkan untuk mencari keuntungan sepihak dan meninggalkan kelompok masyarakat yang lain demi mengejar status kenyamanan yang gamang. Bagi mereka, agama adalah pengontrol kehidupan manusia dari dosa. Berkaitan dengan hal tersebut, permasalahan yang diangkat dalam novel ini terkait dengan kaum agamawan adalah tindakan mereka yang semenamena mengontrol kehidupan perseorangan sehingga tunduk di bawah kekuasaan agamawan. Mereka menggunakan teks-teks kitab suci untuk mengatur tatanan sosial masyarakat melalui orientasi hidup dan perintah atau larangan dalam melakukan tindakan tertentu. Secara rasionalisasi bahwa novel ini menjadi salah satu produk perubahan sosiokultural abad ke-19 berkat pergeseran dominasi agama oleh ilmu pengetahuan di ruang publik. Rasionalisasi mengubah kelas sosial masyarakat yang semula terdiri dari tiga kelas menjadi setara. Selain itu, rasionalisasi mengubah tatanan sosial masyarakat untuk lebih berpusat pada hak-hak perseorangan dan cita-cita duniawi. Keberhasilan kaum borjuasi menyingkirkan peran agamawan, menjadikan rakyat lebih bebas dalam menjalankan agama mereka tanpa adanya kontrol semena-mena dari pihak agamawan.

Pada akhirnya, harus diakui bahwa perkembangan masyarakat dari masa ke masa 
semakin memisahkan jarak antara Gereja dengan Negara, Gereja dengan manusia, dan manusia dengan agama. Industrialisasi merubah pola pikir manusia dari yang semula berpusat pada agama berganti ke arah ambisi duniawi. Akibatnya berpengaruh pula pada pola pikir dan gaya hidup masyarakat. Kegairahan hidup terhadap perkembangan ilmu pengetahuan memunculkan semangat untuk menaikkan kelas sosial sehingga muncul sebuah kelas sosial baru bernama kaum borjuasi (Kuntowijoyo, 2005:161). Peran mereka di dunia ekonomi dan pemerintahan perlahan menggeser posisi kaum agamawan. Gereja yang semula sebagai tempat ibadah dan aktivitas masyarakat (melalui paroki) kemudian hanya menjadi sebuah bangunan yang sepi aktivitas.

\section{UCAPAN TERIMAKASIH}

Artikel ini merupakan hasil dari penelitian payung yang dibiayai oleh dana penelitian Fakultas Ilmu Budaya tahun 2013

\section{DAFTAR PUSTAKA}

Bal, Mieke. (1986). Quelle est la faute de l'abbé Mouret? Pour une narratologie diachronique et polémique. Australian journal of French studies, 23(1), 149-168.

Blockmans, Wim dan Peter Hoppenbrouwers. (2007). Introduction to Medieval Europe 300-1550. Scottland : Routledge.

Brown, F. (1995). The NaturalistZola: A Life (p. 624708744). Farrar, Strauss, Giroux.

Carpentier, Jean dan François Lebrun. (2011). Sejarah Prancis dari Zaman Prasejarah Hingga Akhir Abad Ke-20. Jakarta: KPG (Kepustakaan Populer Gramedia).

Crane, Christina. (1954). "A Study of the Priest in the Novels of Édouard Estaunié". Dalam The French Review, Vol.37, No.4
(Februari 1954). pp. 259-268 (sumber: www.jstor.org/stable/382915 diakses pada 8 April 2013 jam 00.42).

Fairclough, Norman. (2007). Discourse and Social Change. Cambridge: Polity Press.

Houtart, François, dan Rousseau, André. (1971). The Church and Revolution. New York: Orbis Books, Maryknoll.

Husen, Ida Sundari. (2001). Mengenal Pengarang-Pengarang Prancis Dari Abad ke Abad. Jakarta: Grasindo.

Imankatolik. (2013). Dosa Asal. <http:// www.imankatolik.or.id/dosaasal. html> (diakses pada 24 Oktober 2013 jam 11.32).

Kuntowijoyo. (2005). Peran Borjuasi Dalam Transformasi Eropa. Jogjakarta : Penerbit Ombak.

Listiati, Ingrid. (2013). Apakah Perbedaan Nubuat Dan Ramalan?<http://katolisitas.org/1826/apakah-perbedaannubuat-dan-ramalan> (diakses pada 23 Oktober 2013 jam 22.15).

McManners, John.(1998).Church and Society in Eighteenth Century France Volume 1. Oxford : Clarendon Press.

Stearns, Peter N. (1967). European Society in Upheaval : social history since 1800. New York: The Macmillan Company.

Tay, S. dan Listiati, I. (2013). Macam-macam istilah Misa.<http://katolisitas. org/6126/macam-macam-istilahmisa> (diakses pada 22/10/2013 jam 21.35).

Weber, Max. (2012). Sosiologi Agama. Jogjakarta : IRCiSoD.

Zola, Émile. (1875). La Faute de l'Abbé Mouret. Paris : Charpentier 